\title{
Study on the Effect of Consultant communication skills and Consultant job competency on Executive Support and Non- financial Company Performance in the Consulting Industry
}

\author{
*Gowangwoo Park, Ph.D.student, Of Smart Convergence Consulting, Hansung University, 02876, Seoul, \\ Korea, pkmaster@naver.com \\ Yen-Yoo You, Professor, Dept. Of Smart Convergence Consulting, Hansung University, 02876, Seoul, Korea \\ threey0818@hansung.ac.kr \\ *Corresponding Author
}

Abstract. Background/Objectives: The goal of this study is to investigate the relationship of $\mathrm{C}$ onsultant communication skills and Consultant job competency on Non-financial Company Perfo rmance of the company which participating in consulting projects. It is to identify the mediat ing effects of Executive Support.

Methods/Statistical analysis: The subjects of the study focus on project manager of company which had experience of consulting project from professional consultant. Data collection was $\mathrm{c}$ onducted using an NAVER online foam questionnaire. A total of 33 items were measured, inc luding 3 items of general characteristics and 30 items of measurement variables on the Liker $\mathrm{t} 5$ point scale. For empirical analysis of collected data, SPSS Ver. 23 Statistical package was used. The main analyzes were Validity and Reliability analysis, and Multiple regression analysi s.

Findings: This study empirically analyzes the influence of consultant communication skills and consultant competency on the non-financial company performance, which can be represented by the consultant's customer satisfaction consultant competency. And the mediating effect ana lysis of executive support was conducted. The results of the experiment show that there is a correlation between variables measured by consultant communication skills, consultant compet ency, executives support, and non-financial company performance. As a result of the multiple regression analysis, consultant communication skills and consultant job competency were found to have a significant effect of statistic on the non-financial management performance of the company. The higher the communication skills and consultant job competency index, the highe $r$ the non-financial company performance. And, as a result of regression analysis including ex ecutive support as a parameter as a methodology of Baron \& Kenny's mediating effect analys is, it was found that executive support partially mediated the relation between consultant co mmunication skills and consultant job competency on non-financial company performance. As a result of the Sobel Test, which included executive support as a mediating variable, it was found that management support had a mediating effect on consultant communication ability a bout non-financial company performance, but consultant job competency had no mediating effe ct.

Improvements/Applications: This study emphasizes the importance of consultant communication skills and consultant job competency between non-financial company performance in consulti ng industry. It will be an important resource for consultants working on consulting projects. Additional research related to consultant job competency is needed.

Keywords: Consultant communication skills, Consultant job competency, Executive support, Non -financial Company Performance, Customer Satisfaction Competency

Received: 08.12.2020 $\quad$ Accepted: 17.01.2021 $\quad$ Published: 06.02.2021

\section{INTRODUCTION}

In the opinion of the company's executives and CEOs, the consultant is not aware of practicality. A consultant can think of a client as being only for a short-term prospect or goal in making important decisions. A better way is for managers and company advisors to work together to identify needs inside and outside the company and solve problems[1]. As the consulting market develops, there are many positive aspects, but corporate managers and owners still have negative perceptions of consulting. Most managers who manage the entire business of the company lack sufficient expertise or excellent 
experience. Managers often lack knowledge about consulting and do not know about the standard procedure or method of providing consulting, so it takes a long time to decide to receive consulting, or sometimes they are reluctant to implement it[2]. The complex and diverse perspectives of managers often result in insufficient expertise in management. It is a natural process to check whether the consultant has used general knowledge or materials from outside and what form of support has been received[3]. Various studies of CEO have concluded that they lack management expertise, especially in general management areas. It was therefore a natural question to examine whether they used outside sources of management expertise, such as consultants, and for what types of management assistance[4]. Non-formal interviews are an effective way for everybody to know each other, to crush each other, to plan work and to help. People who are close to each other often meet each other, communicate and prepare for what they see, and play a role in helping to keep the conversation going in a mutual relationship[5]. The consultant plays a very important role in all stages, including response to customer readiness, outcomes, customer focus, clear goals, understanding of the environment, an attitude to emphasize success, harmony with internal team members, and expression of outcomes. In outcomes judged to be successful, this phenomenon is more pronounced and we can predict the outcome. Finding the situation and implementing it will certainly increase the likelihood of improvement in ongoing projects[6]. Proper education for the client's managers starts from the first meeting, and should be based on the correct time and data for the proposal. Managers are often bored or curious about the time of the project, but consultants need to quickly inform schedules, share details of progress, and effectively manage these learning factor controls[7]. Loyalty has important implications in marketing and customer and relationship management. Customer satisfaction and communication explain these concepts, and can show correlations or effects between concepts. The customer satisfaction index can be estimated or estimated through customer surveys and can be applied to many areas[8]. For customer satisfaction, surveys through various comparisons and exploration processes are necessary, and it is helpful to conceptualize satisfaction that is not determined cognitively and subjectively, and there are several comparison processes in the formation of satisfaction[9]. Communication plays an important role in building trust, and there is a lack of specific research results on the relationship between the quality and quantity of information, trust and participation. Information anticipates the trust of co-workers, and appropriate information affects the trust of managers as well. In addition, the trust of the manager affects the perception of openness and affects the company goals and level of participation[10]. A process for customer trust and value loyalty that affects trust formation and reduction can be developed, and for this purpose, conceptualization of trust composition, integration of management policies, and investigations of trust and loyalty relationships are meaningful[11]. For successful consulting and strategic decision making, a consultant capable of strategic thinking is needed, and the reason for consulting is lack of expertise, objective help, and quick problem solving. Competencies that are important to success must possess integrity, service quality, communication skills, and job competency[12]. The success and prerequisites of consulting can be considered through systematic research on the relationship between the company and the consultant, and if this is generalized, it will be applicable to the actual consulting industry[13]. Customer satisfaction helps to create policies that create customer awareness and also has a positive effect on improving the quality of our services[14]. Consulting service quality can be evaluated as having an important relationship with customer empathy and responsibility and customer satisfaction[15]. Entrepreneurs have a positive influence on strategy, and entrepreneurs and corporate performance have a mediating effect[16]. Determine what the buyer's personal interests might be(the office decor will often tell you). This trust building may take an hour or a month, but it's always the express lane to conceptual agreement. Consulting is a knowledge service industry that goes through the process of solving customer problems, providing long-term, short-term visions and strategies in a better direction, and solving the current problems. This study empirically demonstrates the relationship between customer satisfaction consultant competency, executives Support, and non-financial performance for project managers who participated in consulting projects to achieve better results in various environments and situations in conducting consulting.

\section{Materials and Methods}

The sample to be surveyed was targeted to the project manager in the company who had experience consulting with a consultant. For the research ethics, the questionnaire of project managers who did not participate in consulting directly was excluded from the survey results.

\section{2-1. Research model}

This study investigates the relationship between consultant communication skills, consultant job competency and non-financial performance of a company through multiple regression analysis through a company project manager who had experience in consulting 
projects. The purpose of this research is to analyze the positive verification for mediating effect of executive support in the relationship between consultant communication skills, consultant job competency and the company's non-financial performance. Based on previous research study, communication skills and consultant job competency were selected as an independent variable, and the dependent variable was selected as the company's non-financial performance. The executive support was selected as the mediator in the relationship between consultant communication skills, consultant job competency and the company's non-financial performance. After research previous studies, the hypothesis of research was established to experimentally analyze the effect relationship to improve performance in the consulting industry. The research model for empirically analyzing this study is shown as below [Figure 1], [Figure 2], [Figure 3].

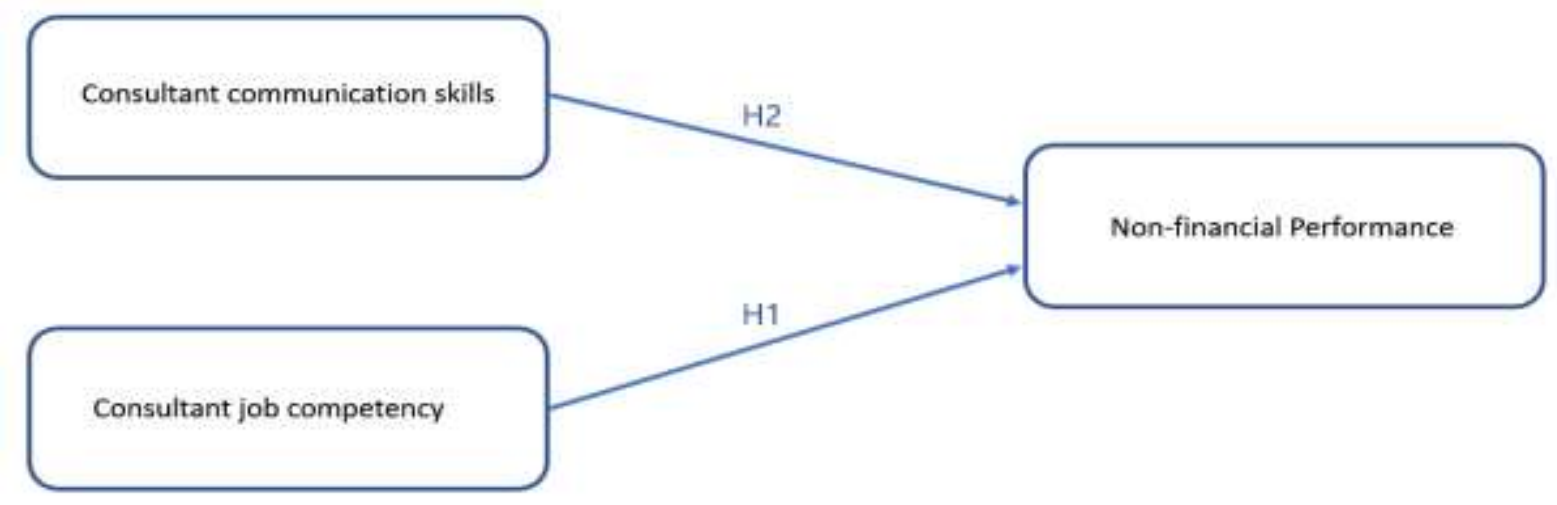

Figure 1. Research model 1

H3 (Mediating effect)

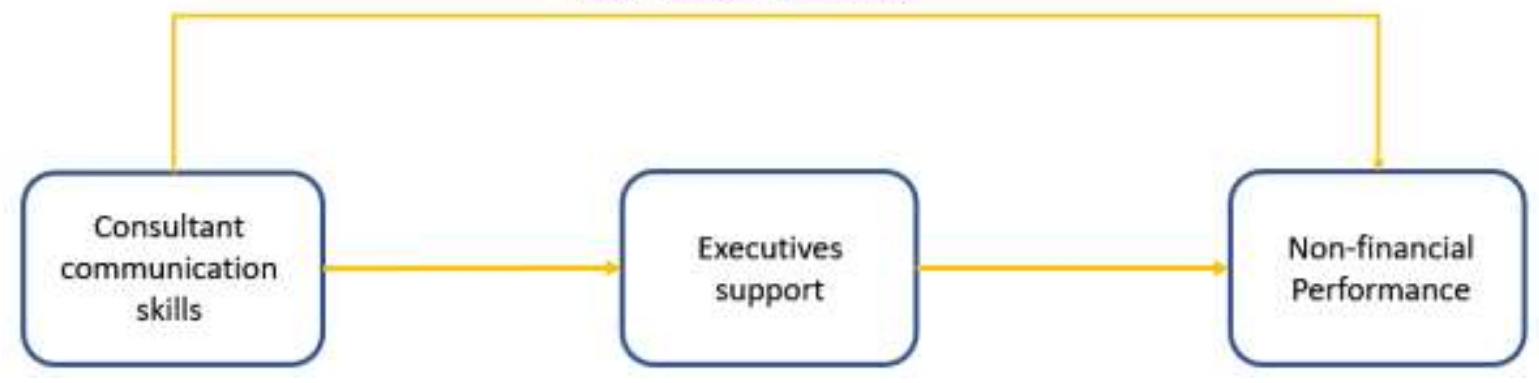

Figure 2. Research model2

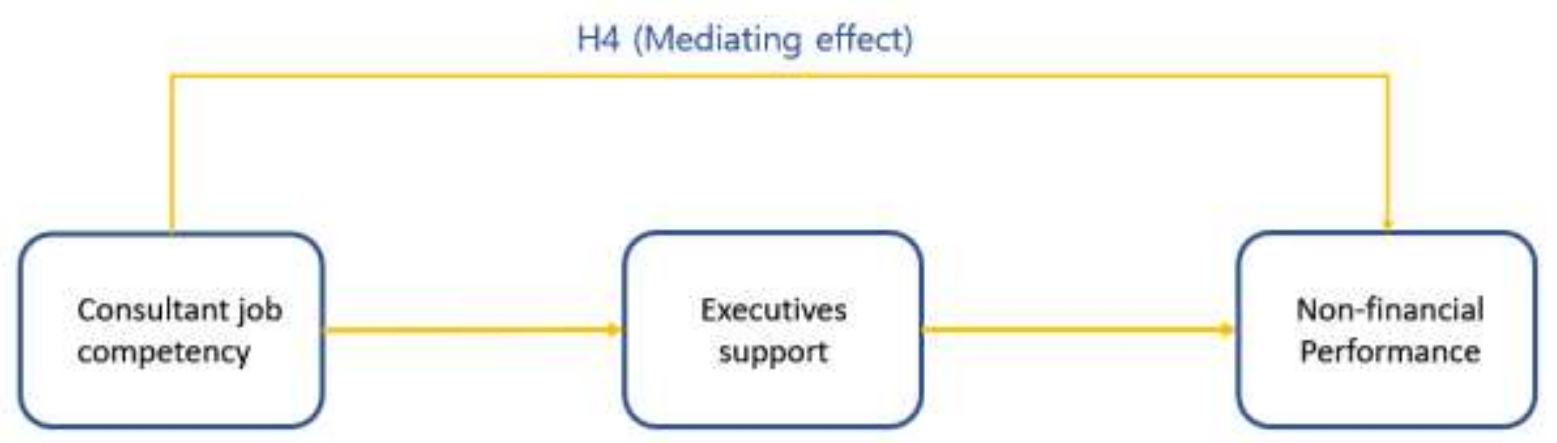

Figure 3. Research model3

\section{2-2. Research Hypothesis}

Based on the research model shown in [Figure 1], the hypothesis about the relationship between the consultant's customer satisfaction competency and the non-financial performance was established. The research hypothesis was set about the mediating effect of executive support in the relationship between customer satisfaction competency and the non-financial performance.

H1. Consultant communication skills will have a positive effect on non-financial company performance. H2. Consultant job competency will have a positive effect on non-financial company performance. 
H3. Executives support will have a mediate the effect of consultant communication skills on non-financial company performance.

H4. Executives support will have a mediate the effect of consultant job competency on non-financial company performance.

\section{2-3. Operational Definition of Variables}

When I checked the previous research, this study divided questionnaire by dividing the customer satisfaction competency of consultant into consultant communication skills and Consultant job competency. Executive support and non-financial performance items were adapted to meet the purpose of this study. The operational definition of the measurement variable and the composition of the questionnaire are summarized as shown in [Table 1].

Table 1. Questionnaire

\begin{tabular}{|c|c|c|c|}
\hline Evaluation items & $\begin{array}{l}\text { Measurement } \\
\text { variable }\end{array}$ & Operational definition & $\begin{array}{l}\text { Configure } \\
\text { questionnaire }\end{array}$ \\
\hline \multirow[t]{2}{*}{$\begin{array}{l}\text { Customer } \\
\text { Satisfaction } \\
\text { Competency }\end{array}$} & $\begin{array}{l}\text { Consultant } \\
\text { communication } \\
\text { skills }\end{array}$ & $\begin{array}{l}\text { clear Answer, active } \\
\begin{array}{r}\text { listening, } \\
\text { effective }\end{array} \\
\text { comprehension, } \\
\text { communication, empathy }\end{array}$ & 5 questions \\
\hline & $\begin{array}{l}\text { Consultant job } \\
\text { competency }\end{array}$ & $\begin{array}{l}\text { strategic thinking, identify problems, } \\
\text { analytical skills, problem solve, } \\
\text { present alternatives }\end{array}$ & 5 questions \\
\hline $\begin{array}{l}\text { Executive } \\
\text { support }\end{array}$ & Executive support & $\begin{array}{l}\text { executive interest, } \\
\text { consulting, team } \\
\text { innovation, risk taking, importance of } \\
\text { organization, } \\
\text { consulting, willingness to conduct }\end{array}$ & 7 questions \\
\hline $\begin{array}{l}\text { Non-financial } \\
\text { Performance }\end{array}$ & $\begin{array}{l}\text { Non-financial } \\
\text { Performance }\end{array}$ & $\begin{array}{l}\text { member satisfaction, internal } \\
\text { communication, company reputation }\end{array}$ & 7 questions \\
\hline \multicolumn{2}{|l|}{ General question } & sex, age, category of consulting & 3 questions \\
\hline
\end{tabular}

\section{Results and Discussion}

\section{3-1. Empirical Results}

\section{3-1-1. Demographic characteristics analysis}

This study collects data collected from consultants currently consulting in the field and used a total of 50 samples for analysis. To understand the distribution of collected samples, Frequency analysis on general characteristics was conducted. The Frequency analysis showed that $84 \%$ (42) were male and 16\% (8) were female. The Age of the 40 s was the highest at $52 \%$ (26), followed by the $50 \mathrm{~s}$ at $30 \%(15)$, and the 40 s and 50 s accounted for $82 \%$. The consulting of management strategy was the highest at 34\%(17), followed by the consulting of marketing at $26 \%(13)$. The remaining consulting category are financial, production innovation, Research and development, Human Resource, Information Technology.

\section{3-1-2. Exploratory factor analysis}

A validity analysis was conducted on consultant communication skills, consultant job competency, executive support, and non-financial management performance of the company. Exploratory factor analysis was executed to verify the validity, PCA(principal component analysis) was used to extract constituent factors, and in order to maximize the division, the Varimax rotation method was used. The KMO value was checked to find out whether this data is appropriate for factor analysis. As a result, it was 0.820 , which exceeded the general level of 0.8. The p-value of the Bartlett's test result is 0.000, and there are at least 1 or more variable is not the unit matrix (correlation between the same variables is 1 , no correlation with other variables). The results of KMO and Bartlett's sphericity test proved to be valid and this data is suitable for factor analysis. The cumulative value of the rotational loading value is $71.734 \%$, exceeding the general level of $60 \%$, so that the four factors sufficiently explain the total variance of the measured variable. The Varimax rotation method used as a rotated component matrix, the factor loading value for each factor exceeds the general level of 0.5 , ensuring concentrated validity. The cross factor loading value was also less than 0.4 , so it could be said that the validity of discrimination was also secured. Since the extracted value of commonality exceeded all of the general standard of 0.5 , there was no questionnaire to be removed. The result of validity analysis as shown in [Table 2].

Table 2. Result of validity analysis

\begin{tabular}{|l|l|l|l|l|}
\hline variable & $\begin{array}{l}\text { executive } \\
\text { support }\end{array}$ & $\begin{array}{l}\text { non-financial } \\
\text { company } \\
\text { performance }\end{array}$ & $\begin{array}{l}\text { consultant } \\
\text { communication } \\
\text { skills }\end{array}$ & $\begin{array}{l}\text { consultant job } \\
\text { competency }\end{array}$ \\
\hline e7 & .853 & & & \\
\hline
\end{tabular}




\begin{tabular}{|c|c|c|c|c|}
\hline e6 & .843 & & & \\
\hline e5 & .814 & & & \\
\hline e4 & .801 & & & \\
\hline e3 & .727 & & & \\
\hline e2 & .708 & & & \\
\hline e1 & .705 & & & \\
\hline p7 & & .805 & & \\
\hline p6 & & .777 & & \\
\hline p5 & & .733 & & \\
\hline $\mathrm{p} 4$ & & .696 & & \\
\hline p3 & & .694 & & \\
\hline p2 & & .652 & & \\
\hline p1 & & .601 & & \\
\hline c4 & & & .772 & \\
\hline c3 & & & .733 & \\
\hline c2 & & & .693 & \\
\hline c1 & & & .688 & \\
\hline $\mathrm{d} 2$ & & & & .851 \\
\hline $\mathrm{d} 1$ & & & & .660 \\
\hline eigenvalue & 5.098 & 4.630 & 2.741 & 2.177 \\
\hline$\%$ variance & 25.491 & 23.152 & 13.705 & 10.883 \\
\hline $\begin{array}{l}\% \\
\text { accumulated }\end{array}$ & 25.491 & 48.643 & 62.348 & 73.231 \\
\hline
\end{tabular}

\section{3-1-3. Reliability analysis}

As a result of reliability analysis on executive support, the overall Cronbach's alpha value (0.927) exceeded the standard value of 0.6 , so it was judged that the reliability was secured. As it is below, it is judged that there is no need for procedures such as removing the measured variable. As a result of reliability analysis on non-financial company performance, the overall Cronbach's alpha value (0.908) exceeded the standard value of 0.6 , so it was judged that the reliability was secured. As it is below, it is judged that there is no need for procedures such as removing the measured variable. As a result of reliability analysis on consultant communication skills, the overall Cronbach's alpha value $(0.831)$ exceeded the standard value of 0.6 , so it was judged that the reliability was secured. As it is below, it is judged that there is no need for procedures such as removing the measured variable. As a result of reliability analysis on consultant job competency, the overall Cronbach's alpha value $(0.753)$ exceeded the standard value of 0.6 , so it was judged that the reliability was secured. The result of reliability analysis shown in [Table3].

Table 3. Result of reliability analysis

\begin{tabular}{|l|l|l|l|}
\hline construct & variable & delete variable Cronbach $\alpha$ & Cronbach $\alpha$ \\
\hline executive support & e7 & 0.912 & \multirow{2}{*}{0.927} \\
\cline { 2 - 3 } & e6 & 0.913 & \\
\cline { 2 - 3 } & e5 & 0.916 & \\
\cline { 2 - 3 } & e4 & 0.912 & \\
\hline
\end{tabular}




\begin{tabular}{|c|c|c|c|}
\hline & e3 & 0.918 & \\
\hline & e2 & 0.921 & \\
\hline & e1 & 0.917 & \\
\hline \multirow[t]{7}{*}{ non-financial company performance } & p7 & 0.891 & \multirow[t]{7}{*}{0.908} \\
\hline & p6 & 0.879 & \\
\hline & p5 & 0.914 & \\
\hline & $\mathrm{p} 4$ & 0.886 & \\
\hline & p3 & 0.891 & \\
\hline & $\mathrm{p} 2$ & 0.903 & \\
\hline & $\mathrm{p} 1$ & 0.893 & \\
\hline \multirow[t]{4}{*}{ consultant communication skills } & $\mathrm{c} 4$ & 0.805 & \multirow[t]{4}{*}{0.831} \\
\hline & c3 & 0.775 & \\
\hline & $\mathrm{c} 2$ & 0.792 & \\
\hline & $\mathrm{c} 1$ & 0.774 & \\
\hline \multirow[t]{2}{*}{ consultant job competency } & $\mathrm{d} 2$ & & \multirow[t]{2}{*}{0.753} \\
\hline & $\mathrm{d} 1$ & & \\
\hline
\end{tabular}

\subsubsection{Correlation analysis}

Through Exploratory factor analysis, this study eliminated measurement items that impeded intensive and discriminant validity. It consisted of four measured variables calculated through Reliability analysis. Correlation analysis was performed to investigate the density and directional of the measured variables. In the correlation between the measured variables in Table 4, consultant job competency showed high correlation with non-financial company performance of $.664^{* *}$ by Pearson correlation coefficient and followed consultant communication skills and executive support of .593**. The correlation analysis results of all the measured variables showed statistically significant positive correlations. It is judged that regression analysis between the constructs is possible. The Correlation analysis results are summarized as shown in [Table 4].

Table 4. Result of correlation analysis

\begin{tabular}{|c|c|c|c|c|c|}
\hline & & $\begin{array}{l}\text { executive } \\
\text { support }\end{array}$ & $\begin{array}{l}\text { non- } \\
\text { financial } \\
\text { company } \\
\text { performance }\end{array}$ & $\begin{array}{l}\text { consultant } \\
\text { communication } \\
\text { skills }\end{array}$ & $\begin{array}{l}\text { consultant } \\
\text { job } \\
\text { competency }\end{array}$ \\
\hline \multirow[t]{3}{*}{$\begin{array}{l}\text { executive } \\
\text { support }\end{array}$} & $\begin{array}{l}\text { Pearson } \\
\text { Correlation }\end{array}$ & 1 & $.573^{* *}$ & $.593^{* *}$ & $.302^{*}$ \\
\hline & $\begin{array}{ll}\text { Sig. } \\
\text { tailed) }\end{array}$ & & .000 & .000 & .033 \\
\hline & $\mathrm{N}$ & 50 & 49 & 50 & 50 \\
\hline \multirow{3}{*}{$\begin{array}{l}\text { non-financial } \\
\text { company } \\
\text { performance }\end{array}$} & $\begin{array}{l}\text { Pearson } \\
\text { Correlation }\end{array}$ & $.573^{* *}$ & 1 & $.530^{* *}$ & $.664^{* *}$ \\
\hline & $\begin{array}{ll}\text { Sig. } \\
\text { tailed) }\end{array}$ & .000 & & .000 & .000 \\
\hline & $\mathrm{N}$ & 49 & 49 & 49 & 49 \\
\hline \multirow{3}{*}{$\begin{array}{l}\text { consultant } \\
\text { communication } \\
\text { skills }\end{array}$} & $\begin{array}{l}\text { Pearson } \\
\text { Correlation }\end{array}$ & $.593^{* *}$ & $.530^{* *}$ & 1 & $.566^{* *}$ \\
\hline & $\begin{array}{l}\text { Sig. } \\
\text { tailed) }\end{array}$ & .000 & .000 & & .000 \\
\hline & $\mathrm{N}$ & 50 & 49 & 50 & 50 \\
\hline
\end{tabular}




\begin{tabular}{|l|l|l|l|l|l|}
\hline $\begin{array}{l}\text { consultant job } \\
\text { competency }\end{array}$ & $\begin{array}{l}\text { Pearson } \\
\text { Correlation }\end{array}$ & $.302^{*}$ & $.664^{* *}$ & $.566^{* *}$ & 1 \\
\cline { 2 - 6 } & $\begin{array}{l}\text { Sig. } \\
\text { tailed) }\end{array}$ & .033 & .000 & .000 & \\
\cline { 2 - 6 } & $\mathrm{N}$ & 50 & 49 & 50 & 50 \\
\hline
\end{tabular}

\subsubsection{Hypothesis test result}

Multiple regression analysis was performed to figure out the effect of consultant communication skills, consultant job competency on non-financial management performance. VIF of all independent variables was below 10, so that there was no multicollinearity problem between independent variables. Since the coefficient of Durbin-Watson is far from 0 and 4 and close to 1.515 from 2, the independence of the residual term is also secured. This data is suitable for regression analysis. In the analysis of variance table, the $\mathrm{F}$ value was $27.581, \mathrm{p}<0.000$, indicating that any one of the independent variables had a linear effect on the dependent variable. As a result of checking the coefficient table to find out which variable among the independent variables linearly affects the dependent variable. Consultant job competency $\mathrm{p}=0.006$, consultant communication skills $\mathrm{p}=0.002$, all had statistically significant effects. The nonstandardization coefficient B is all positive, and the higher the consultant job competency and consultant communication skills, the higher the non-financial management performance. Hypothesis 1 and Hypothesis 2 were both adopted. The degree of impact on non-financial management performance was identified as the absolute value of the standardization coefficient beta, and it was shown in the order of consultant job competency (0.381) and consultant communication skills (0.429).

Table 5. Summary of Multi- regression Analysis Results

\begin{tabular}{|l|l|l|l|l|l|l|l|}
\hline $\begin{array}{l}\text { Hypothesi } \\
\mathrm{s}\end{array}$ & Constructs & $\mathrm{B}$ & $\beta$ & $\mathrm{t}$ & $\mathrm{p}$-value & VIF & Results \\
\hline $\mathrm{H} 1$ & (Constant) & -0.598 & & -1.072 & 0.289 & & \\
\hline $\mathrm{H} 2$ & $\begin{array}{l}\text { consultant job } \\
\text { competency }\end{array}$ & 0.472 & 0.381 & 2.882 & 0.006 & 1.772 & accept \\
\hline $\begin{array}{l}\text { consultant } \\
\text { n skills }\end{array}$ & 0.565 & 0.429 & 3.240 & 0.002 & 1.772 & accept \\
\hline
\end{tabular}

$\mathrm{R} 2=.545$, Adjusted R2=.526, F=27.581(p = <.001), Durbin-Watson=1.515, Dependent variable : nonfinancial company performance

\subsubsection{Mediated effect analysis}

In the model 1, the Durbin-Watson is 1.771 close to 2 , so the independence of the residual term is secured so that this data is suitable for regression analysis. The consultant communication skills, on the mediating variable, the executive support (Baron \& Kenny's 2nd stage: independent variable -> mediating variable), it has a statistically significant ( $\mathrm{p}=0.000)$ positive effect appeared. In step 2(Baron \& Kenny's 1 step + 3 step: independent variable + mediating variable -> dependent variable), the mediating variable executive support is statistically significant to the dependent variable non-financial company performance $(\mathrm{p}=0.008)$. It was found to have a positive effect and there is a mediating effect. In the step 1 (Baron \& Kenny's Step 1: independent Variable -> dependent Variable), the independent variable of consultant communication skills (standardization coefficient), the independent variable in step 2, the consultant communication skills, the regression coefficient (standardization coefficient) statistically, it decreased significantly [0.593->0.294], indicating that the executive support partially mediated the impact of the consultant communication skills on the non-financial company performance.

In the model 2, the Durbin-Watson is 1.435 close to 2 , so the independence of the residual term is secured and this data is suitable for regression analysis. The consultant job competency, on the mediating variable, the executive support (Baron \& Kenny's 2nd stage: independent variable -> mediating variable), it has a statistically significant $(\mathrm{p}=0.000)$ positive effect appeared. In step 2 (Baron \& Kenny's 1 step +3 step: independent variable + mediating variable $\rightarrow$ dependent variable), the mediating variable executive support is statistically significant to the dependent variable non-financial company performance $(\mathrm{p}=0.000)$. It was found to have a positive effect and there is a mediating effect. In step 1 (Baron \& Kenny's Step 1: independent variable -> dependent variable), the independent variable of consultant job competency (standardization coefficient), the independent variable in step 2, the consultant job competency, the regression coefficient (standardization coefficient) statistically, it decreased significantly 
[0.670->0.541], indicating that the executive support partially mediated the impact of the consultant job competency on the non-financial management performance.

Table 6. Summary of Mediating effect results from regression analysis

\begin{tabular}{|c|c|c|c|c|c|c|}
\hline \multicolumn{7}{|c|}{$\begin{array}{l}\text { Regression analysis by independent variable consultant } \\
\text { communication skills }\end{array}$} \\
\hline \multirow[t]{3}{*}{ Model 1} & Step1 & & Step2 & & Step3 & \\
\hline & \multicolumn{2}{|c|}{$\begin{array}{l}\text { Dependent variable: } \\
\text { non-financial } \\
\text { company } \\
\text { performance }\end{array}$} & \multicolumn{2}{|c|}{$\begin{array}{l}\text { Dependent variable: } \\
\text { executive support }\end{array}$} & \multicolumn{2}{|c|}{$\begin{array}{l}\text { Dependent } \mathrm{v} \\
\text { non-financial co } \\
\text { performance }\end{array}$} \\
\hline & $\mathrm{B}$ & Beta & $\mathrm{B}$ & Beta & B & Beta \\
\hline (Constant) & 0.748 & & 0.701 & & 0.467 & \\
\hline $\begin{array}{l}\text { consultant } \\
\text { communication skills }\end{array}$ & 0.691 & $.530 * * *$ & 0.735 & $.593 * * *$ & 0.383 & $.294^{*}$ \\
\hline executive support & & & & & 0.416 & $.399 * *$ \\
\hline $\mathrm{R}^{2}$ (Adjusted $\mathrm{R}^{2}$ ) & $\begin{array}{l}.281 \\
(.266)\end{array}$ & & $.352(.338)$ & & $.385(.358)$ & \\
\hline F-value & $18.402^{* * *}$ & & $26.022^{* * *}$ & & $14.369^{* * *}$ & \\
\hline Durbin-Watson & 1.771 & & 1.718 & & 1.752 & \\
\hline \multicolumn{7}{|c|}{$\mathrm{p}$-value: $* \mathrm{P}<.05, \quad * * \mathrm{p}<.01, \quad * * * \mathrm{p}<.001$} \\
\hline \multicolumn{7}{|c|}{$\begin{array}{l}\text { Regression analysis by independent variable consultant } \\
\text { job competency }\end{array}$} \\
\hline \multirow[t]{3}{*}{ Model 2} & Step1 & & Step2 & & Step3 & \\
\hline & \multicolumn{2}{|c|}{$\begin{array}{l}\text { Dependent variable: } \\
\text { non-financial } \\
\text { company } \\
\text { performance }\end{array}$} & \multicolumn{2}{|c|}{$\begin{array}{l}\text { Dependent variable: } \\
\text { executive support }\end{array}$} & \multicolumn{2}{|c|}{$\begin{array}{l}\text { Dependent variable: } \\
\text { non-financial company } \\
\text { performance }\end{array}$} \\
\hline & $\mathrm{B}$ & Beta & $\mathrm{B}$ & Beta & B & Beta \\
\hline (Constant) & 0.256 & & 2.232 & & -0.699 & \\
\hline $\begin{array}{l}\text { consultant job } \\
\text { competency }\end{array}$ & 0.822 & $.664^{* * *}$ & 0.355 & $.302 *$ & 0.670 & $.541 * * *$ \\
\hline executive support & & & & & 0.429 & $.411 * * *$ \\
\hline $\mathrm{R}^{2}$ (Adjusted $\mathrm{R}^{2}$ ) & $\begin{array}{l}.442 \\
(.430)\end{array}$ & & $.091(.72)$ & & $.595(.578)$ & \\
\hline F-value & $37.158^{* * *}$ & & $4.815^{*}$ & & $33.852^{* * *}$ & \\
\hline Durbin-Watson & 1.435 & & 1.854 & & 1.262 & \\
\hline
\end{tabular}

\subsubsection{Sobel Test for the Significance of Mediation}

Sobel Test was conducted to verify the mediation effect, and the test URL is

https://www.danielsoper.com/statcalc/calculator.aspx?id=31. The B value of unstandardized coefficients on consultant communication skills is 0.735 which is input data on A. The standard error value of the nonstandardization factor of consultant communication skills is 0.416 , which is input data on $B$. The B value of unstandardized coefficients on executive support is 0.144 which is input data on SEA. The nonstandardization coefficient standard error value of executive support is 0.150, which is input data on SEB. The Sobel test statistic value is 2.436 which is higher than 1.96 . There is a mediating effect and the Sobel test is also significant shown in [Figure 4]. 


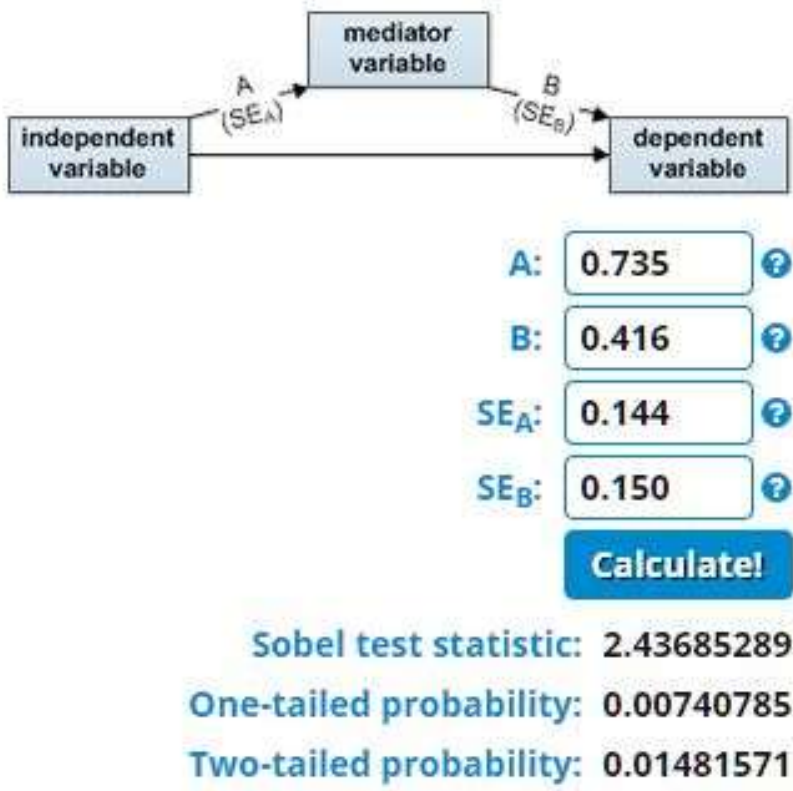

Figure 4. Sobel Test 1

The B value of unstandardized coefficients on consultant job competency is 0.355 which is input data on A. The standard error value of the non-standardization factor of consultant job competency is 0.429 , which is input data on B. The B value of unstandardized coefficients on executive support is 0.162 which is input data on SEA. The non-standardization coefficient standard error value of executive support is 0.102 , which is input data on SEB. The Sobel test statistic value is 1.94 which is less than 1.96. There is no mediating effect and the Sobel test is not significant shown in [Figure 5].

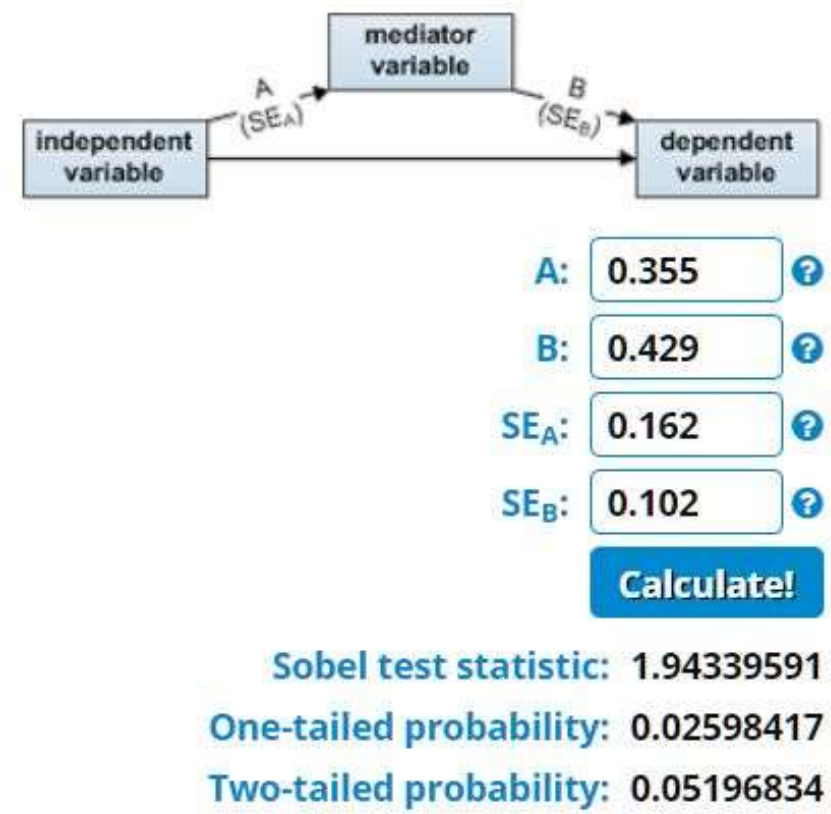

Figure 5. Sobel Test 2

\section{Conclusions}

With the rapid change in innovated technology like Robotics, artificial intelligence,

nanotechnology, quantum programming, biotechnology, IoT, 3D printing and autonomous vehicles, and the increase in uncertainty due to the worldwide corona epidemic, companies are able to secure more competitiveness and manage long-term strategies as well as short-term execution tactics and problem solving by securing more competitiveness with Finance, Marketing, R\&D, IT consulting projects and there are increasing cases where professional consultants are being used. Consulting projects implemented on the basis of consultant communication skills and consultant job capabilities have an impact on increasing 
the non-financial management performance of a company, and prior research and empirical analysis that support from corporate management will mediate these impact relationships in conducting consulting projects. This study was initiated through and the hypothesis was verified through questionnaire and statistical analysis. There were several limitations in this study. We used a lot of time to find a project manager who performed a consulting project and getting an honest answer from this subject, and we were not able to secure enough number of questionnaires. The evaluation included many subjective opinions of each project manager, and consulting projects did not reflect the opinions of various project managers executed in various countries, including only those executed in Korea. In a future study, consultants, project managers, and executives who work hard in the consulting front by constructing various variables other than the above-mentioned variables based on more sufficient samples of consulting project managers executed in various countries and analyzing the impact relationship between each variable. We plan to conduct follow-up research that is helpful to all.

\section{Acknowledgements}

This research was financially supported by Hansung University.

\section{References}

[1] AN Turner. (1982) Consulting is more than giving advice. Harvard Business Review , 60(5), pp. 120 129.

[2] Barisic, A. \& Bozicevic, M. (2013) Role of Management Consulting in a Process of Professionalization of SME Management. Journal of Entrepreneurial Learning, 3 (2) p 144-159

[3] Knight, Russell; Johnson, Richard; Leduc, Raymond. (1991) THE RELATIONSHIP BETWEEN ENTREPRENEUR AND CONSULTANT. Journal of Small Business and Entrepreneurship; Toronto Vol. 8, Iss. 3.

[4] Gallese V. (2007) Before and below 'theory of mind': embodied simulation and the neural correlates of social cognition. Philosophical Transactions of the Royal Society B: Biological Sciences. 2007 Apr 29;362(1480):659-69.

[5] Kraut RE, Fish RS, Root RW, Chalfonte BL. (1990) Informal communication in organizations: Form, function, and technology. In Human reactions to technology: Claremont symposium on applied social psychology 1990 Jan 1:145-199

[6] Appelbaum, S. H. and Steed, A. J. (2005) The Critical Success Factors in The Client-Consulting Relationship. The Journal of Management Development, 24(1/2), pp. 68-93.

[7] Alan Weise. (2007) Million Dollar Consulting. McGraw-Hill,New York,USA

[8] D Ball, PS Coelho, A Machás. (2003) The Role of Communication and Trust in Explaining Customer Loyalty. European journal of marketing,38(9/10),1272-1293.

[9] Tse, D. K. \& Peter, C. W. (1988) Models of Consumer Satisfaction: An Extension. Journal of Marketing Research, May,204-212.

[10] Thomas, G. \& Zolin, R. \& Hartman, J. (2009) The Central Role of Communication in Developing Trust and its Effects on Employee Involvement. Journal of Business Communication, 46(3),287-310.

[11] Sirdeshmukh, D., Singh, J., \& Sabol, B. (2002) Consumer Trust, Value and Loyalty in Relational Exchanges. Journal of Marketing,66(1),15-37.

[12] Simon Alan and Vanya Kumar. (2001) Clients' views on strategic capabilities which lead to management consulting success. Management Decision,Vol.39,Issue5,pp.362-372.

[13] Rynning,M. (1992) Successful consulting with small and medium-sized vs large clients:meeting the needs of the client?.International Business Journal,11(1), pp. 47-60.

[14] Nimitha Kateel; Navin Kumar Koodamara. (2018) A Study on Patient Satisfaction: Differences in Private and Public Hospitals. International Journal of Emerging Multidisciplinary Research, 2(1), 33 39. DOI: 10.22662/IJEMR.2018.2.1.033

[15] William C. Alcantara. (2019) The Classification and Quality of Service and Hotel Customers' Satisfaction. International Journal of Emerging Multidisciplinary Research, 3(3), 23-32. DOI: 10.22662/IJEMR.2019.3.3.023

[16] Yunsoo Shim and Jounghae Seo (2019) A Study on Entrepreneurial Orientation and Startup Performance: Mediating Effect of Strategic Orientation. International Journal of Emerging Multidisciplinary Research, 3(4), 33-41. DOI: 10.22662/IJEMR.2019.3.4.033. 